\title{
New Records of the Fish Genus Grammatonotus (Teleostei: Perciformes: Percoidei: Callanthiidae) from the Central Pacific, Including a Spectacular Species in the Northwestern Hawaiian Islands ${ }^{1}$
}

\author{
Bruce C. Mundy and Frank A. Parrish ${ }^{2}$
}

\begin{abstract}
A second species of Grammatonotus from the Hawaiian Islands, tentatively identified as G. macrophthalmus Katayama, Yamamoto \& Yamakawa (Callanthiidae), is recorded from French Frigate Shoals and the Northampton Seamount based on observations from a research submersible. In the absence of collected specimens, identification was made by comparing characters visible in video images with previously published images and descriptions. The fish were observed from 340 to $440 \mathrm{~m}$ at or near rocky habitats with crevices. All of the observations were near current-swept areas that supported gold coral (Gerardia sp.) colonies, although the fish were never seen within the colonies. A habitat feature important for both Grammatonotus and Gerardia, such as current or planktonic food supply, may therefore influence distribution of the fish. Extensive fish surveys conducted in comparable depths at other areas of the archipelago have not encountered this species, with one poorly documented exception from trawling surveys. Two other range extensions of Grammatonotus are included herein: Grammatonotus laysanus Gilbert from the Line Islands with a specimen collected at Christmas Island at $274 \mathrm{~m}$ and an unidentified Grammatonotus juvenile from the Tuamotu Archipelago at $705 \mathrm{~m}$. Our examination of specimens and review of previous records of Grammatonotus indicate that this genus needs taxonomic revision.
\end{abstract}

The Fish Fauna of the Hawaiian Islands is better known than that of any other Pacific island group. Despite this, species previously unrecorded from these Islands continue to be found. Many of these are small and/or deepwater species from poorly sampled habitats. In this paper, we document spectacularly col-

${ }^{1}$ Supported in part by an award from the National Undersea Research Program's Hawai'i Undersea Research Laboratory to the NOAA Fisheries Honolulu Laboratory's Ecosystems and Environment Investigation. Dives at the Northampton Seamount were funded by an award from the NOAA Ocean Explorations Initiative. Participation in this cruise by B. Mundy was part of the NOAA Fisheries Honolulu Laboratory Coral Reef Ecosystem Investigation multivessel 2001-2002 surveys of reef and reef-associated ecosystems in the Northwestern Hawaiian Islands. Manuscript accepted 22 July 2003.

${ }^{2}$ National Marine Fisheries Service (NOAA Fisheries), Pacific Islands Fisheries Science Center, Honolulu Laboratory, 2570 Dole Street, Honolulu, Hawai'i 96822.

Pacific Science (2004), vol. 58, no. 3:403-417

Work of the U.S. Government

Not under copyright ored examples of one such species (Plate I) tentatively identified as Grammatonotus macrophthalmus Katayama, Yamamoto \& Yamakawa, 1982. The fish were encountered during submersible dives in the Northwestern Hawaiian Islands but could not be collected. Our identification is therefore based on comparisons of video images with published descriptions, illustrations, and photographs.

The only previous reference found to $G$. macropbthalmus in the Hawaiian Islands is Fujii's (1986) brief review of seamount fish biogeography, which includes the species in a table with the annotation "ESC, HI" (for the Emperor Seamount Chain and Hawaiian Islands). No other information was given. Given the scarcity of information on this species, the publication of our observations is warranted.

\section{MATERIALS AND METHODS}

Observations were made during Hawai'i Undersea Research Laboratory (HURL) Pisces 


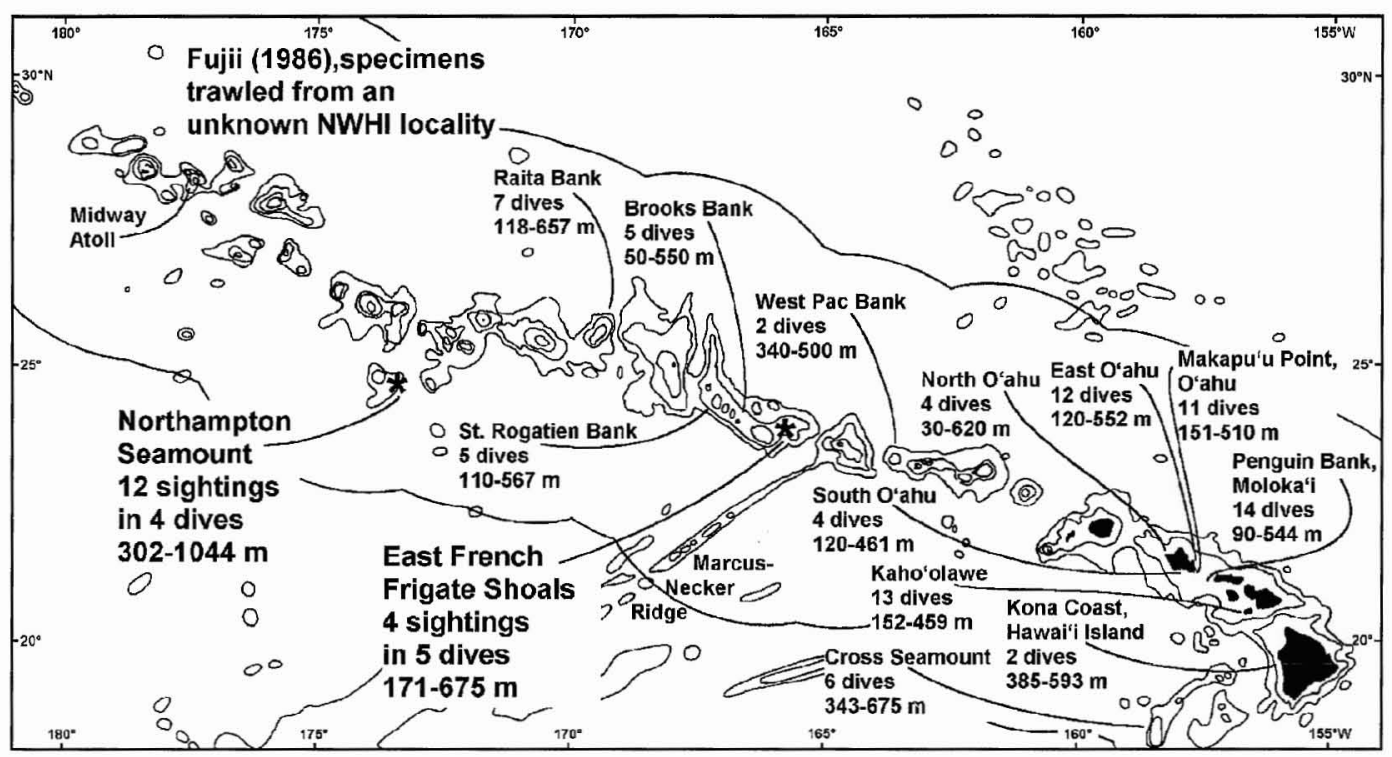

FIGURE 1. Locations in the Hawaiian Islands where Grammatonotus macrophthalmus has been observed from HURL Pisces submersibles (asterisks) and locations where other Pisces submersible fish census dives were conducted during 1997-2002. The number of dives and their combined depth ranges (meters) are given for each location.

$V$ submersible dives in the Northwestern Hawaiian Islands (NWHI) (Figure 1) on 8-9 September 2001 at the east extension of the French Frigate Shoals (FFS) platform $\left(23^{\circ}\right.$ $55^{\prime} \mathrm{N}, 165^{\circ} 23^{\prime} \mathrm{W}$ ) and on 20 September 2002 at the Northampton Seamount $\left(25^{\circ}\right.$ $\left.16.9^{\prime} \mathrm{N}, 172^{\circ} 01.3^{\prime} \mathrm{W}\right)$. The dives (P5-455456 , P4-055) were conducted to survey deepwater foraging areas of the endangered Hawaiian monk seal, Monachus schauinslandi Matschie. The FFS location contains a gold coral (Gerardia species) bed, where seals from the FFS colony are known to feed (Parrish et al. 2002), with colonies encrusting pinnacles spread over a 2 -ha area. Submersible surveys of this bed were conducted in 1998 (one dive), 2000 (one dive), and 2001 (two dives). The Northampton Seamount site is also a foraging area for seals (Brent Stewart, Hubbs Sea World, pers. comm., October 2002), but the deepwater habitat was unexplored before the three dives of our 2002 survey. All submersible dives lasted 6-7 hr at the bottom. The dive objectives were to identify, count, and obtain size estimates of potential monk-seal prey species associated with the precious corals and adjacent habitats. These dives were conducted in conjunction with another set of submersible surveys that looked at fish assemblages at the same depths and in similar habitats at several other Northwestern and main Hawaiian Islands locations (Figure 1).

Collections of fishes were not possible, so all counts and measurements were taken from video images and are therefore approximate. The images had no calibrated scale for measurements. Therefore, morphometric data are expressed as proportions of a relative reference measurement (typically standard length [SL], head length [HL], or postorbital length) taken in the same video frame. Measurements were those given as diagnostic for Grammatonotus species by Katayama et al. (1982) and Anderson (1999), using landmarks specified therein. Measurements were taken with dividers from individual frames on the video screen and checked to the nearest $0.5 \mathrm{~mm}$ against a ruler. Measurements were taken from only those frames that best showed a fish viewed either laterally for most measurements or dorsally for head, interorbital, and 
body widths, without foreshortening of the fish's image from turning. Images in which individual fish were filmed at close range in the frame's center were used to avoid image distortion at frame edges and to reduce measurement error due to small image size relative to measurement precision. Only two individuals were filmed adequately for measurements to be taken. Images of one of these allowed us to obtain many body measurements, but the other allowed only head measurements. Therefore, single values are given for most body proportions, but a range of values is given for some head proportions. Grammatonotus specimens at the NOAA Fisheries Honolulu Laboratory (NMFs) and the Bernice P. Bishop Museum (врвм) collections were examined to obtain comparative data, as were photographs of $G$. crosnieri (Fourmanoir) provided by W. Anderson (Grice Marine Biological Laboratory).

\section{RESULTS}

\section{Observations}

Our first sighting of G. macropbthalmus was of two individuals at FFS (Figure 1) at $352 \mathrm{~m}$ by submersible pilot T. Kerby and F.A.P. The fish were obviously unlike any previously seen during thousands of hours of submersible observations in the Hawaiian Islands at comparable depths, including previous surveys in the same area. The most distinctive characteristics of the fish were their striking color patterns and elongated tails. The slow movement of one of the fish stunned by the bright light of the submersible enabled F.A.P. to record close-up video images with the submersible's digital video system (Plate I). Examination of the video by the scientists aboard the R/V Ka'imikai-o-Kanaloa in the evening after the dive led to unanimous agreement that the fish was not a species recorded from the Hawaiian Islands in taxonomic reviews of the fishes available at that time (e.g., Chave and Mundy 1994, Randall 1996, Mundy in press, and references cited therein).

Four sightings of the fish at FFS, at 350$360 \mathrm{~m}$, occurred in 2 days of diving. Two fish were seen together on 8 September 2001, and three fish were seen individually on 9 September 2001. The first sighting of the second day was at the same location as the initial sighting and was possibly one of the individuals seen on 8 September. We therefore suspect that we observed four individuals at three sites within the same general area of the bank.

On 20 September 2002, 12 individuals of this species were found at a second location, the Northampton Seamount (Figure 1). The first sighting at this location was of a single individual at $440 \mathrm{~m}\left(9.5^{\circ} \mathrm{C}\right)$ on a flat carbonate substrate (that at first appeared not to be near high-relief habitat). The fish took cover inside a small crevice as the submersible approached. The substrate changed to a sheer vertical wall, estimated to be over $100 \mathrm{~m}$ high, a few dozen meters away from the site of this first observation. A second sighting of the species on this dive occurred at a ledge and crevice on the wall face at $420 \mathrm{~m}\left(9.8^{\circ} \mathrm{C}\right)$, just up-current of a ridge with colonies of gold coral. One individual was again seen briefly as it took cover under a small arch at the crevice on the cliff face. Ten more individuals were seen after the submersible moved up to $340 \mathrm{~m}$ $\left(12.1^{\circ} \mathrm{C}\right)$ and traveled downcurrent over flat carbonate substrate at the top of the cliff face. All of the fish were seen close to small crevices within which they took shelter. As with the first sighting of the species at this location, no high-relief substrate was visible immediately adjacent to the crevices where the fish were seen, but the drop-off to the cliff was just beyond our range of vision. All of these individuals quickly hid in crevices so that video images could not be obtained at the Northampton Seamount.

\section{Description}

The sizes of the fish were not measured directly but were approximately $20 \mathrm{~cm}$ total length and $12 \mathrm{~cm}$ SL.

The greatest body depth was 3.6 in SL. The eye diameter (2.0-2.3 in HL) was greater than the postorbital length (2.4-2.9 in $\mathrm{HL})$. The body was elongate and compressed. The body width at the pectoral-fin bases was 
6.4 in SL. The caudal peduncle length was greater than its depth, 1.7 in HL. The dorsal profile of head was gently convex from the dorsal origin to the blunt, rounded snout. The snout was short, ca. 4.3-5.1 in HL. The interorbital width was narrower than the eye diameter, 2.6 in HL. The head width was 4.8 in SL and 1.6 in HL. The mouth was moderately large and oblique. The maxilla reached below the anterior edge of the pupil, 2.3 in HL. The nostrils, teeth, opercular morphology, scale morphology, and lateral line pores were not visible. The dorsal fin was unnotched, with XI spines and 9 soft rays. The other fin elements were not countable. The insertion positions of the fins with respect to other landmarks were not accurately determinable. The third anal spine was longer than the first dorsal spine but not accurately measurable. The shortest dorsal fin spine was the first, 4.4 in $\mathrm{HL}$. The longest dorsal fin spine was probably the seventh, 2.3 in HL. The longest dorsal soft ray and longest anal soft ray were each ca. 1.1 in HL. The pectoral fin length was not measurable. The pelvic fin length was 3.8 in SL. There were 10 caudal rays produced into filaments, the longest 1.2 in SL. About 27 scale rows were counted from the nape to the caudal fin when viewed dorsally.

\section{Coloration}

Under dim illumination when first seen at distance, the fish were uniformly pale whitish blue with brighter bluish white pelvic fins and distal tips of the filamentous caudal fin rays. When illuminated next to the submersible (Plate I), the fish showed the following colors: The body was golden yellow from the posterior head to the abdomen, grading posteriorly to golden ocher on the tail to the base of the caudal fin. The snout and interorbital area to the insertion of the dorsal fin were magenta. The dorsum under the dorsal fin and on the caudal peduncle was lavender pink. Five triangular pink areas extended from the dorsal stripe ventrally on the dorsal one-third of the sides, approximately beneath spinous dorsal-fin rays $2-5,7-9,3-5,8-9$ and beneath middle of caudal peduncle. The middle three areas extended as bars ventrally on the sides, becoming faint on the lower sides. There was a stripe of diffuse magenta behind the eye to the posterior opercular edge. The iris was silvery except lavender dorsally. The chin, branchial region, thorax, and anterior ventral abdominal region were diffuse light blue, appearing gray in shadow when viewed from above. The pectoral fin was transparent. The pelvic fin was reflective bluish white anteroventrally with bright white tips, becoming translucent greenish white posterodorsally. The dorsal fin was golden ocher proximally, with a light blue stripe on its upper half and a purple stripe with pink spinous and soft ray tips distally. There was a second light blue stripe on lower half to onethird of the spinous dorsal-fin rays posteriorly. The anal fin was light ocher proximally, with a light blue stripe on the proximal onethird to half, a distal purple stripe, and lavender pink tips on the spinous and soft rays. The caudal fin base was golden ocher, the free filaments of the central rays were blue, the outer rays were purple with magenta outer edges, and the tips of the filamentous rays were pale bluish white at some angles.

\section{Habitat and Behavior}

The fish were observed in a variety of habitats at 340-440 m, but all of the sites were near high-relief areas free of sediments, indicative of strong currents. Colonies of gold coral (Gerardia sp.) were found near the areas where the species was observed, but the fish were never seen within the immediate area of the colonies.

The fish at FFS were observed at mixed basalt cobble and sand patches at or near undercut basalt outcroppings of moderate (0.5-1 m) relief, adjacent to high-relief basalt outcrops that had bushes of gold coral. The 2-ha coral bed is the only known habitat of this composition at FFS. Four of the sightings were close to outcrops, but one observation was of a fish swimming ca. $1 \mathrm{~m}$ above flat, semiconsolidated substrate many meters away from the nearest shelter. The species was not observed during extensive surveys (2$4 \mathrm{~km}$ in length) radiating $\mathrm{N}, \mathrm{S}, \mathrm{E}$, and $\mathrm{W}$ 
from the coral bed in 1998, 2000, and 2001, over uniform carbonate and manganese crust bottom that composes the east extension of the FFS platform. The gold coral bed was the shallowest point, at $350-360 \mathrm{~m}$, on the platform, which had depths of 370-400 $\mathrm{m}$ at most of its highest area. The fish were seen near the coral beds or on the area of bottom immediately adjacent (ecotonal) to the coral pinnacle. Temperatures at this site were 9.1$14.0^{\circ} \mathrm{C}$, logged by temperature recorders left there for a year.

The fish at the Northampton Seamount were mostly seen on flat carbonate substrate covered with a thin layer of sediment and with small crevices, adjacent to a vertical carbonate wall. One individual was seen at a larger unsedimented crevice with an arch on this wall. No basalt was present at the Northampton Seamount site. Gold coral colonies on this wall were growing on a sharpedged ridge, several meters downcurrent of the arched crevice where one of the fish was found and several dozens of meters below the top of the wall where most of the fish were seen. The fish at the Northampton Seamount were seen at 340-440 m where temperatures were $9.5-12.1^{\circ} \mathrm{C}$. No long-term temperature records are available from the Northampton Seamount. This fish species was not seen on two other dives at the Northampton Seamount, even though those dives were in the same depth range and included habitats with gold coral colonies similar to the habitats where the fish were seen on 20 September 2002.

The fish either were stunned by the submersible's lights or, in most sightings, moved quickly to shelter within crevices. All individuals swam slowly with labriform motion, sculling with their pectoral fins, keeping their bodies straight and their caudal fins widespread, until alarmed by the submersible's proximity. When startled, they darted rapidly with tail flexions.

The fish were seen singly or in pairs, but not in larger groups. However, we cannot discount the possibility that other Grammatonotus with different color patterns and shorter caudal fins, seen near the long-tailed fish, could have been other life-history stages of the same species.
DISCUSSION

\section{Identification}

The morphology of the fish suggested that they were a member of the family Callanthiidae, although many diagnostic characters that distinguish the Callanthiidae from superficially similar taxa (Anthiinae, Symphysanodontidae) found in this depth range were not visible in the video images. Those characters include the lateral line morphology, the number of spines on the opercular bone, the internal morphology of the nasal organ, the branchiostegal ray number, and the microornamentation of the scales. Key morphological features used to identify the fish as callanthiids include the presence of spines on the fins, thoracic pelvic fins, an undivided and unnotched dorsal fin, the relative lengths of the dorsal and anal fins, the number of dorsal spines as indicated by incised notches along the dorsal edge of that fin's membrane, the shapes and sizes of the fins, the number of scale rows, the short rounded snout, and the eye size (Plate I, Table 1). Comparison of these characters with Carpenter's (1999) review of characters diagnostic for central $\mathrm{Pa}$ cific teleost families eliminates all families except the Callanthiidae for these fish.

The characters that unequivocally differentiate callanthiid genera (Anderson and Johnson 1984) are not visible without specimens in hand, although our tentative dorsalfin soft ray count agrees with Grammatonotus (8-10, usually 9 rays) instead of Callanthias (10-11 rays, rarely 12). Most Callantbias species are deeper bodied with shorter snouts than Grammatonotus (see Masuda et al. 1984, Anderson 1999). We also infer that Pacific Callanthias species have more scale rows (>33) than Grammatonotus (25-26 [Table 1]), although we have found no direct comparison of this in the literature. We reached this conclusion from the following comparison of the various methods of counting longitudinal body scales used in various taxonomic treatments of callanthiids. The number of tubed lateral-line scales is 25-42 in Callanthias (see Anderson and Johnson 1984) versus 14-17 in Grammatonotus (see Katayama et al. 1980, Katayama et al. 1982, Anderson 1999). The 
TABLE 1

Counts and Proportions of the Putative Grammatonotus macropbthalmus from French Frigate Shoals and Other Pacific Grammatonotus Species

\begin{tabular}{|c|c|c|c|c|c|}
\hline Character & $\begin{array}{l}\text { French Frigate } \\
\text { Shoals Fish* }\end{array}$ & G. macrophtbalmus & G. laysanus & G. surugaensis & G. crosnieri \\
\hline Standard length (mm) & ca. 120 ? & $95-119$ & 129 & $63-81$ & $35-119$ \\
\hline Dorsal fin elements & XI,9? & XI,9 & XI,9 & $\mathrm{XI}, 9$ & XI,9 \\
\hline Scale rows & 27 (25?) & 25 & 26 & $25-26$ & $25-26$ \\
\hline Body depth in SL & 3.6 & $3.00-3.50$ & $3.07-3.31$ & $2.79-2.93$ & $2.4-3.3^{*}$ \\
\hline Body width in SL & 6.4 & $5.89-7.19$ & $6.59-7.17$ & $5.73-6.41$ & No data \\
\hline Pelvic fin length in SL & 3.8 & $3.63-4.46$ & & $3.63-4.05$ & $2.8-5.4 ?^{\star}$ \\
\hline Caudal fin length in SL & 1.2 & $1.18-1.85$ & $1.79-1.87$ & $2.25-3.06$ & $1.01-1.03^{*}$ \\
\hline Snout length in HL & $4.3-5.1$ & $4.43-5.70$ & $4.19-4.67$ & $4.80-5.25$ & $5.44-8.00^{*}$ \\
\hline Orbit diameter in HL & $2.0-2.3$ & $2.17-2.43$ & $2.55-2.59$ & $2.63-2.68$ & $2.17-2.82^{*}$ \\
\hline Upper jaw length in HL & 2.3 & $2.24-2.50$ & $2.20-2.21$ & $2.18-2.92$ & $2.17-2.80^{*}$ \\
\hline Interorbital width in $\mathrm{HL}$ & 2.6 & $3.11-3.57$ & $3.26-3.50$ & $2.74-2.92$ & No data \\
\hline $\begin{array}{l}\text { Postorbital head } \\
\text { length in HL }\end{array}$ & $\begin{array}{l}2.4-2.9, \leqq \text { orbit } \\
\text { diameter }\end{array}$ & $\begin{array}{l}2.30-2.67 \\
\quad<\text { orbit diameter }\end{array}$ & $\begin{array}{l}>\text { orbit } \\
\text { diameter }\end{array}$ & $>$ orbit & $\begin{array}{l}1.86-2.63,{ }^{*} \\
\leqq \text { orbit diameter }\end{array}$ \\
\hline $\begin{array}{l}\text { Caudal peduncle } \\
\text { length in HL }\end{array}$ & 1.7 & $1.53-1.74$ & $1.33-1.45$ & $1.78-1.94$ & $1.16-1.72^{*}$ \\
\hline $\begin{array}{l}\text { Caudal peduncle } \\
\text { depth in HL }\end{array}$ & 2.2 & $1.89-2.24$ & $1.83-2.08$ & ca. $1.78-1.94$ & $1.63-1.98^{*}$ \\
\hline $\begin{array}{l}\text { Length of 1st dorsal } \\
\text { spine in HL }\end{array}$ & 4.4 & $5.42-6.84$ & & & $3.76-7.00^{*}$ \\
\hline $\begin{array}{l}\text { Length of longest dorsal } \\
\text { spine in HL }\end{array}$ & 2.3 & $2.13-2.53$ & $2.44-2.33$ & $2.24-2.40$ & $1.46-2.18^{*}$ \\
\hline $\begin{array}{l}\text { Length of longest dorsal } \\
\text { ray in HL }\end{array}$ & 1.1 & $1.09-2.23$ & $1.33-1.38$ & $1.63-1.85$ & $0.96-1.41^{*}$ \\
\hline $\begin{array}{l}\text { Length of longest anal } \\
\text { ray in HL }\end{array}$ & 1.1 & $1.09-1.77$ & $1.22-1.40$ & $2.08-2.63$ & $0.81-1.58^{*}$ \\
\hline
\end{tabular}

Sources: Our data for the French Frigate Shoals fish; Katayama et al. (1980) for G. surugaensis; Katayama et al. (1982) and Matsuura and Tachikawa (1994) for G. macrophthalmus; Katayama et al. (1982) for G. laysanus; and Fourmanoir (1981), Anderson (1999), and unpublished photographs provided by W. Anderson for $G$. crosnieri.

${ }^{*}$, data from photographs.

lateral line in callanthiids ends near the dorsal-fin insertion or on the caudal peduncle (Anderson 1999), so the number of lateralline scales is less than or equal to the number of midbody lateral scales or scale rows. Pacific Callanthias species have $>33$ lateral-line scales with the exception of $C$. parini Anderson \& Johnson, which, although it has only 25-30 lateral-line scales, has 38-46 midbody lateral scales (Anderson and Johnson 1984). We were unable to count tubed lateral-line scales in our images, but 27 scale rows were observed dorsally on the FFS fish. We consider this to be congruent with the 25-26 scale rows reported for Grammatonotus species (Katayama et al. 1980, Katayama et al. 1982) because our count included scales at the nape not included in the scale row counts taken from specimens. The fish observed by us thus agree with Pacific Grammatonotus species instead of Pacific Callanthias species in body depth, snout length, dorsal-fin spine count, and lateral-scale row count.

The identification of our fish to species proved more problematic. Four species, $G$. laysanus Gilbert, 1905; G. surugaensis Katayama, Yamakawa \& Suzuki, 1980; G. macrophthalmus Katayama, Yamamoto \& Yamakawa, 1982; and G. crosnieri (Fourmanoir, 1981), were included in the most recent reviews of the genus (Katayama et al. 1982, Kanou et al. 2003). Grammatonotus crosnieri was not included in Katayama et al. (1982), likely because it was originally described as being in a different genus, Callantbias, at approximately the same time as their paper was 
written. Two other species have been omitted from most publications on callanthiids. Heliastes roseus Günther, 1880, described from the Ki (Kai) Islands, Arafura Sea, Indonesia, is also a Grammatonotus species of uncertain status (W. Anderson, Grice Marine Biological Laboratory, pers. comm., November 2002). (Kanou et al. [2003] stated that $C$. roseus is a pomacentrid, but only the genus Heliastes is a synonym of a pomacentrid taxon.) Fourmanoir (1976) gave G. laysanus as a junior synonym of $G$. roseus (as Zabulon roseus), but this hypothesis needs reevaluation. Parabarossia lanceolata Kotthaus, 1976, described from Socotra Island, northwestern Indian Ocean, was listed by Eschmeyer (1998) as a valid callanthiid species in that third genus, but in Eschmeyer's (1998) list of genera, Parabarossia was considered a synonym of Grammatonotus following Springer (1982) and Mooi (1993). This also needs more investigation (W. Anderson, Grice Marine Biological Laboratory, pers. comm., November 2002).

The Grammatonotus species most similar to the one in our images is $G$. macropbthalmus, as shown by a photograph of a badly damaged trawled specimen in Okamura et al. (1982:220), reprinted in Masuda et al. (1992). This fish has a general appearance that matched that of the fish in our images, including greatly produced caudal rays with a violet or bluish lavender color. But the fish illustrated in Okamura et al. (1982) lacks the distinctive color pattern of our fish, described on their p. 373 as "Body yellowish pink. Dorsal and anal fins with pink margins. Caudal fin pink. Pectoral and pelvic fins pale pink." This description does not match our images. The original description of the color of G. macropbthalmus (Katayama et al. 1982:373) also does not match the fish we observed: "Body yellowish pink; iris pink; dorsal and anal fins with pink margins; caudal fin pink; pectoral and pelvic fins pale pink."

The identity of our fish is revealed by the photograph of G. macropbthalmus in Okamura and Amaoka (1997:280). Their photograph also seems to be of a damaged, trawled specimen, but unlike the photograph in Okamura et al. (1982), it shows a dorsal stripe and bars on the upper one-third of the body similar to those in our images. The color values of the markings of the photograph in Okamura and Amaoka (1997) differ from our images in being more red, but the pattern is almost identical. Differences in the head and anterior body shape can be explained as the difference between our specimen photographed alive and Okamura and Amaoka's (1997) specimen photographed after death, probably by suffocation when brought to the surface. Similarities in the color pattern of this image with ours include a dorsal stripe with bars extending ventrally down the upper one-third of body, with four of these bars under the dorsal fin and the fifth on the upper center of caudal peduncle; a bluish lavender upper edge on the iris; dark edges to the tips of the dorsal and anal fin elements and membrane edges, with these fins otherwise yellow or yellow orange; a yellow orange ground color to most of the lateral body and caudal peduncle below the dorsal stripe and bars; a yellow orange proximal center of the caudal fin; and purple, blue, and bluish lavender greatly prolonged free caudal rays. This unusual shared color pattern, along with the general appearance and fin morphology of the fish in our images and in Okamura and Amaoka (1997) convinced us that our fish are best identified as G. macrophthalmus, pending collection of specimens.

The fish observed at FFS shared morphometric characters only with $G$. macrophthalmus among the species reviewed by Katayama et al. (1982) (Table 1). In addition, the eye diameter described for G. roseus (scarcely twofifths of head length [Günther 1880]) does not match that of either the fish observed at FFS or G. macropbtbalmus (Table 1). The eye diameter of $G$. lanceolatus is 2.3 in HL but is less than the postorbital length as calculated from other head measurements given in the description of the species (Kotthaus 1976). (Osteological and larval pigment characters used by Kanou et al. [2003] to identify juvenile Grammatonotus were not available from our visual observations.)

Sufficient descriptive detail was therefore given for all nominal Grammatonotus species to make our identification with confidence, with one exception. The original description of $G$. crosnieri gave only body depth as mor- 

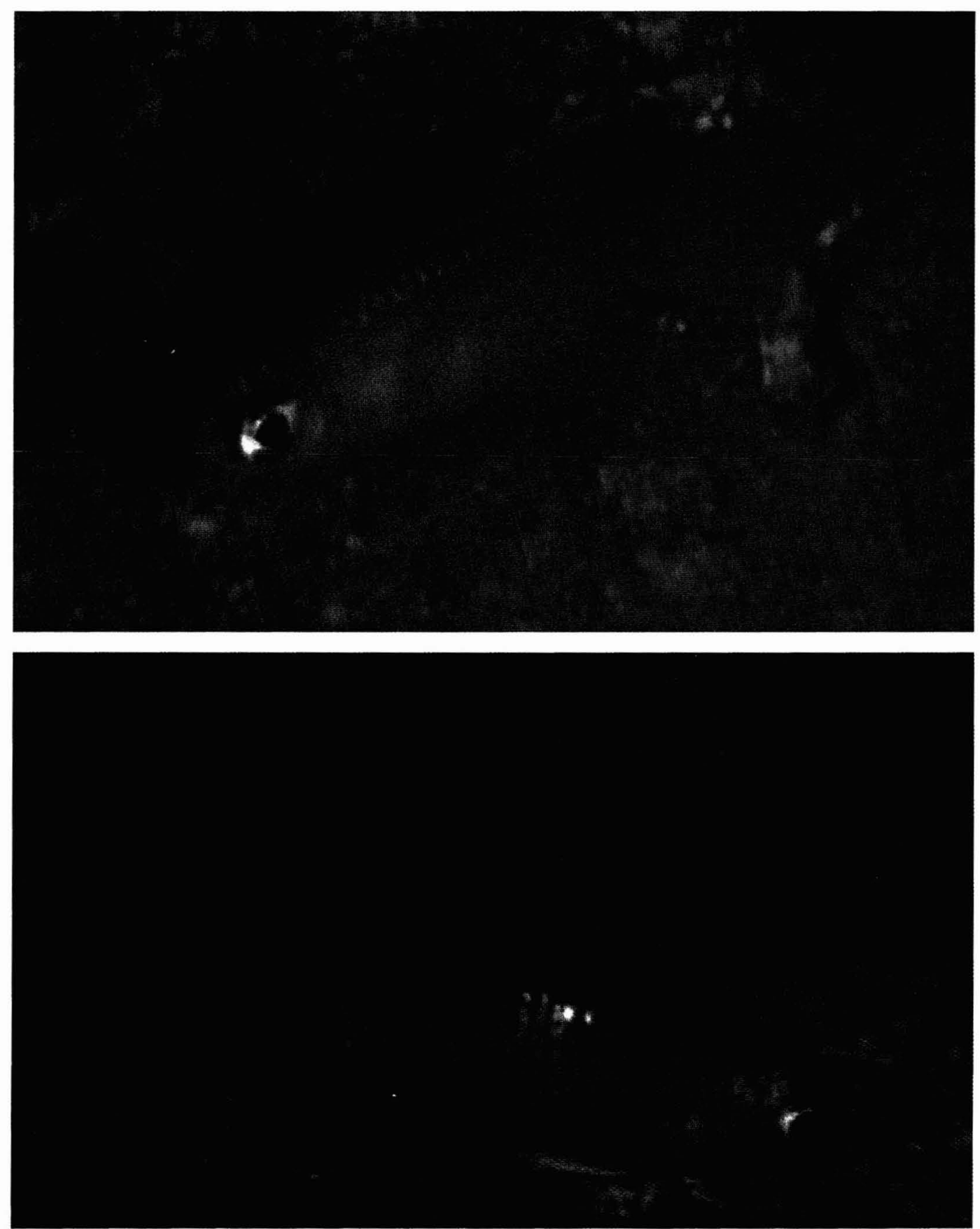

Plate 2. Top, An unidentified Grammatonotus species with a diamond-shaped caudal fin photographed from the Hawai'i Undersea Research Laboratory Pisces $V$ submersible at 248 m, Penguin Banks, Moloka'i, Hawai'i (HURL dive P5-426; submersible pilot, C. Holloway; camera operator, C. Kelley). Bottom,. A color variety of Grammatonotus laysanus? photographed from the Hawai'i Undersea Research Laboratory Pisces $V$ submersible at $372 \mathrm{~m}$, Cross Seamount, southwest of Hawai'i Island, Hawai'i (HURL dive P5-501; submersible pilot, T. Kerby; camera operator, C. Kelley). 
small juveniles. It is noteworthy, however, that larval and pelagic juvenile Grammatonotus from $\mathrm{O}^{\prime} \mathrm{ahu}$ and the Hancock Seamounts in our collection (NMFs HLIP-1, $18.7 \mathrm{~mm}$ SL; HLIP-34, $4.2 \mathrm{~mm} \mathrm{SL}$ ) have orbit diameters shorter than the postorbital head length, as has been described for larvae and juveniles from other regions (Fourmanoir 1976, Miskiewicz et al. 2000, Kanou et al. 2003). The use of this character for species identification of juvenile Grammatonotus therefore needs further evaluation.

\section{Ecology and Biogeography}

Previous records of $G$. macropbthalmus are from the Kyushu-Palau Ridge at 300-500 m (Okamura and Amaoka 1997), from a beached specimen in the Ogasawara Islands (Matsuura and Tachikawa 1994), and from unspecified depths in the Emperor Seamounts and Hawaiian Islands (Fujii 1986). Our observations from 340 to $440 \mathrm{~m}$ are therefore within the known depth range of the species.

A habitat attribute shared by the Hawaiian Archipelago sites where G. macropbthalmus was observed is proximity to high-relief substrate with gold coral colonies. Gold corals grow at ca. $300-500 \mathrm{~m}$ in areas where currents sweep planktonic food organisms through the colonies and sweep sediments away from the habitat (Grigg 1974 as Parazoanthus sp., 1984, Parrish et al. 2002). Little else is known about the habitat requirements of gold corals. The fish were not seen within the colonies, only near them. We therefore suggest that there are shared habitat requirements such as currents and food supply that promote the proximity of the fish and the coral. We also note that both species are very patchy and clumped in their known distributions within the Hawaiian Archipelago. Gold corals are known from many more areas than are G. macropbtbalmus.

Fujii's (1986) records of G. macropbthalmus from the Hawaiian Islands are likely from the northwestern part of the ridge, given the known distributions of the other species included in his paper. (We attempted to contact E. Fujii to obtain more information, but were unsuccessful.) Fujii (1986) cited Japan Fisheries Agency (1974) as a source of information for his record. Grammatonotus macropbthalmus was not mentioned in that report, but unidentified Serranidae were, and Grammatonotus was placed in the Serranidae at that time. Within the Hawaiian Ridge, unidentified serranids were collected at an "unsurveyed bank" (26 $18-19^{\prime} \mathrm{N}, 174^{\circ} 31-32^{\prime}$ $\mathrm{W}=$ Bank 8$)$, the Ladd Seamount $\left(28^{\circ} 31-\right.$ $\left.34^{\prime} \mathrm{N}, 176^{\circ} 35-43^{\prime} \mathrm{W}\right)$, and the Hancock Seamounts $\left(29^{\circ} 46^{\prime}-30^{\circ} 18^{\prime} \mathrm{N}, 179^{\circ} 02-48^{\prime}\right.$ $\mathrm{E})$, all well to the northwest of FFS and the Northampton Seamount (Japan Fisheries Agency 1974). Grammatonotus macropbthalmus has not been seen in numerous other submersible and remotely operated vehicle surveys south of FFS in the Northwestern and main Hawaiian Islands (Chave and Mundy 1994, Chave and Malahoff 1998) (Figure 1). Twenty-six other fish species are recorded in the archipelago from only the NWHI (Mundy in press).

Grammatonotus macrophthalmus undoubtedly occurs at locations within the NWHI other than the two from which our observations came. Its patchy distribution, limited depth range, and habitat preferences make observation and sampling of it difficult. As suggested before, the proximity of G. macrophthalmus to high-relief substrate would limit its susceptibility to capture by trawling. Grammatonotus species are not taken in traps and are too small to be taken by conventional hook and line fishing methods. Numerous submersible observations in the Northwestern Hawaiian Islands have not found $G$. macrophthalmus, but many of the submersible surveys in which fishes were the primary target have focused on depth ranges other than those at which the species occurs (Chave and Mundy 1994, Chave and Malahoff 1998) (Figure 1).

Grammatonotus macrophthalmus is otherwise known only from the Kyushu-Palau Ridge at ca. $26^{\circ} 13.5-47.2^{\prime} \mathrm{N}, 135^{\circ} 20.7-$ 52.1' E (Katayama et al. 1982) and the Ogasawara Islands (Matsuura and Tachikawa 1994, Kanou et al. 2003). It is one of 57 species known only from the western North $\mathrm{Pa}$ cific and the Hawaiian Islands, including 37 
demersal or benthic species (Mundy in press). Other examples of western North Pacific and Hawaiian Islands deep-dwelling demersal fishes are Gymnothorax ypsilon Hatooka \& Randall, Lopbioides miacantbus (Gilbert), Hoplostetbus crassispinus Kotlyar, Satyrichtbys engyceros (Günther), Parapercis roseoviridis (Gilbert), and an unnamed Argyripnus species that was also found for the first time in the Hawaiian Islands during our surveys. It is possible that the ranges of some deepwater species with distribution patterns limited to the western North Pacific, the Emperor Seamounts, and Hawaiian Islands are artifacts of limited deepwater sampling at Pacific islands. As an example, G. laysanus was reported as a Johnston Atoll, Hawaiian Islands, and Emperor Seamount endemic species (e.g., Katayama et al. 1982, Randall et al. 1985) until it was found at the Sala-y-Gómez Ridge during deepwater trawling (Parin et al. 1997). (Earlier reports of $G$. laysanus juveniles from midwater sampling at New Caledonia [Fourmanoir 1971, 1976] were overlooked, but the identifications of the New Caledonian specimens need reevaluation considering the problematic taxonomy of the genus.) However, some of the 57 western North Pacific and Hawaiian Islands species are well sampled and easily identified, indicating that their known distribution is not a sampling artifact.

When G. macrophthalmus was found in a limited area at FFS in 2001, the question arose as to whether the fish seen were waifs or part of a previously unrecorded resident species with a reproducing population. The discovery of Fujii's (1986) records and the sightings of more individuals at the Northampton Seamount support our contention that $G$. macropbthalmus is a resident Hawaiian Archipelago species.

The discovery of $G$. macrophthalmus in the Hawaiian Islands prompts inquiry into the origins of its occurrence there. Contemporary biogeographic theory suggests that the distributions of Hawaiian Archipelago marine organisms have been formed primarily from vicariance linked with changing ocean circulation and colonization of the archipelago from other areas via larval dispersal and stepping-stones of suitable adult habitat
(Grigg and Bayer 1976, Grigg 1981, Springer 1982, Randall et al. 1985, Randall 1996, Mundy in press). Two pathways proposed in the literature seem possible to connect the Hawaiian Archipelago with the western North Pacific: (1) the Subtropical Countercurrent (STCC) moving over the region of the Marcus-Necker Ridge and (2) the Kuroshio/North Pacific Current moving from the Kyushu-Palau Ridge past Japan and the Ogasawara Islands and then eastward to the Emperor Seamounts and northernmost end of the Hawaiian Ridge.

The Marcus-Necker Ridge extends southwestward of and includes Necker Island, the island nearest to FFS (Grigg and Bayer 1976). The STCC, a seasonably variable current of broad latitudinal extent and poorly defined relative to the Kuroshio Extension current to the north (Qiu 1999), is assumed to flow intermittently over this ridge (Grigg 1981). The Marcus-Necker Ridge extends westward from the NWHI to the Line Island Ridge north of Johnston Atoll, giving an easily seen connection at least that far. But westward of Johnston Atoll only isolated groups of deep seamounts continue the connection to the Ogasawara Islands or Kyushu-Palau Ridge. In addition, even the shallowest portion of the Marcus-Necker Ridge near the Hawaiian Islands is at depths of 1,660-2,693 m, deeper than the habitat for G. macrophtbalmus. This would have been true even during known sea level regressions (Grigg and Bayer 1976). The distances between stepping-stones along the Marcus-Necker Ridge seem too great for the ridge to have been the most likely conduit for dispersal of G. macrophthalmus to the $\mathrm{Ha}$ waiian Islands on any time scale.

In contrast, the stronger and more consistent Kuroshio Extension connects the western Pacific to the Hawaiian Islands by flowing from southern Japan to the northernmost Hawaiian Islands. This has been suggested as a mechanism for colonization of the Hawaiian Islands by western North Pacific fish species (Randall et al. 1985). This pathway is likely less general for Hawaiian Islands fishes than has been suggested, but its efficacy is supported by the $4.6 \%$ of the fauna ( 57 species) with ranges restricted to the west- 
ern North Pacific and the Hawaiian Islands (Mundy in press). Grammatonotus macrophthalmus is one of those species. We are not implying by this that G. macropbthalmus is a recent colonist of the Hawaiian Islands, however. The genetic differentiation of the species throughout its range would have to be studied before the antiquity of its distribution pattern could be determined.

Little is known about the early life histories of callanthiids to support or refute hypotheses about their dispersal (Trnski and Miskiewicz 1998, Miskiewicz et al. 2000). A prolonged larval duration for the genus might be indicated by the relatively large size of pelagic juveniles ( $23 \mathrm{~mm}$ SL [Miskiewicz et al. 2000]), as well as by the size of newly settled juveniles that retained larval pigment patterns (32 and $39 \mathrm{~mm}$ SL: врвм 37191 and 37135). But such inferences from larval and juvenile sizes need verification from otolith daily growth ring analysis before they can be considered valid. And even with such precise information, pelagic larval durations are poorly correlated with dispersal abilities, as measured by geographic ranges (Jones et al. 2002).

\section{Additional Taxonomic Problems with Grammatonotus Species in the Hawaiian Islands}

Three morphological phenotypes of Grammatonotus have been observed during Pisces $V$ submersible surveys in the Hawaiian Islands, raising the question of how many species exist in the archipelago. These phenotypes are distinguished by the shape and extensions of rays of the caudal fin: (1) double-emarginate with filamentous outer principal rays (these appear as round tails without filaments when viewed at a distance from the submersible), identified as G. laysanus; (2) broomlike, with extremely long, filamentous caudal fin rays, identified as $G$. macropbthalmus; and (3) diamond-shaped or lanceolate (Plate II, top). The diamond-tailed phenotype has not been identified to species.

Two photographs by J. E. Randall identified as G. laysanus on the International Center for Living Aquatic Marine Resources FishBase online database (http://www.fishbase
.org/Photos/ThumbnailsSummary.cfm?ID= 27474) show fish with (1) a damaged caudal fin that appears to be double emarginate with a filamentous upper principal ray and (2) a diamond-shaped caudal fin without filaments. The image of the fish with a double emarginate caudal fin with filaments matches $G$. laysanus by having an eye diameter less than the postorbital head length. The image of the fish with the lanceolate tail has an eye diameter equal to the postorbital length, casting doubt on that specimen's identity.

It has been suggested that callanthiids are protogynous hermaphrodites (Anderson 1999). It was also suggested that Callanthias parini is sexually dimorphic, with larger individuals having longer dorsal, anal, and caudal fin rays than smaller individuals (Anderson and Johnson 1984). One hypothesis for the identity of the diamond-tailed phenotype is that it could be the juvenile and/or female morph of one or both of the other species. The diamond-tailed Grammatonotus and $G$. laysanus are sometimes seen together but are more often seen in groups of only one type (C. Kelley, HURL, pers. comm., November 2001). The G. macrophthalmus individuals that we observed are much larger than the diamond-tailed fish, but we have seen $G$. laysanus that are smaller, the same size, and larger than the diamond-tailed phenotype.

Seven specimens of Grammatonotus were available to us, but of these two are recently settled juveniles, one is a pelagic juvenile, and one is a larva. The three largest specimens (врвм 22757, $123 \mathrm{~mm} \mathrm{SL}$; NMFsH P-113, $145 \mathrm{~mm} \mathrm{SL}$; врвм 39292, $62 \mathrm{~mm} \mathrm{SL}$ ) all have double emarginate tails with filamentous outer principal rays. The smaller specimens (врвм 37191, $39 \mathrm{~mm} \mathrm{SL}$; врвм 37135, $32 \mathrm{~mm}$ SL; NMFs HLIP-1, 18.7 mm SL; NMFs HLIP$34,4.2 \mathrm{~mm} \mathrm{SL}$ ) have broken caudal fin rays but appear to have had slightly lanceolate to truncate caudal fins. This does not refute the suggestion that caudal fin shape is related to reproductive state in this genus, but insufficient specimens were available to investigate this further. We cannot reject the hypothesis that the diamond-tailed Grammatonotus is a third Hawaiian Islands species. 
An additional complication in our efforts to identify Grammatonotus from submersible observations arose from color and fin morphology differences in fish that otherwise appear to be $G$. laysanus. Randall et al. (1985) described and published a photograph of $G$. laysanus at Johnston Atoll with a white or red spot on the back and elongate pelvic, soft dorsal, and anal fins. Although those authors stated that this morph was also seen in the main Hawaiian Islands, it was not found in numerous main Hawaiian Islands observations in recent years (Figure 1). It was observed again in November 2002 at Cross Seamount $\left(18^{\circ} 40^{\prime} \mathrm{N}, 158^{\circ} 17^{\prime} \mathrm{W}\right)$, southwest of Hawai' $i$ Island but far northeast of Johnston Atoll (C. Kelley, HURL, pers. comm., December 2002) (Plate II, bottom). We can say no more about this morph at present, except to note that it adds yet another mystery to be solved in Grammatonotus taxonomy and life history.

\section{Other New Records of Grammatonotus Species}

Two specimens of Grammatonotus that we examined were collected from the Line Islands and the Tuamotu Archipelago, island groups for which we found no previous records of the genus. A third specimen was collected in the Hawaiian Islands, but in exceptionally shallow water. These records are therefore also included in this paper.

A juvenile $G$. laysanus (врвм 37191, $39 \mathrm{~mm}$ SL) was collected at Kahe Point, O'ahu, by J. Culp with a hand net on sand at the remarkably shallow depth of $7.6 \mathrm{~m}$. The fish was not remembered as being noticeably unhealthy despite being so far above its usual depth range (J. Culp, University of Hawai'i HURL, pers. comm., June 2003). It had remnants of the larval pigment pattern, suggesting that it was recently settled. We know of no other record of the genus from such shallow water, except for the G. macrophtbalmus that washed up on a beach in the Ogasawara Islands (Matsuura and Tachikawa 1994).

The other newly settled juvenile (врвм 37135) was collected by J. Poupin with a dredge at $705 \mathrm{~m}$ at Hao Atoll, Tuamotu Archipelago $\left(18^{\circ} 4^{\prime} 12^{\prime \prime} \mathrm{S}, 141^{\circ} 20^{\prime} 12^{\prime \prime} \mathrm{W}\right)$. To our knowledge, this is the first record of the genus from French Polynesia. As mentioned before, this specimen has an orbit diameter diagnostic of G. macrophthalmus, but we are reluctant to assign a species identification to such a small specimen in a group diagnosed almost entirely by subtle morphometric differences and differences in adult color pattern, fin morphology, tooth morphology, and other characters likely not to be fully developed in larvae and juveniles. Osteological characters are useful for identification of juvenile Grammatonotus (see Kanou et al. 2003), but we were unable to examine the osteology of the specimens on loan to us.

The NOAA Fisheries Honolulu Laboratory had in its collection one specimen (now врвм 39292, 62 mm SL) from Christmas Island, Line Islands, taken in a shrimp trawl at $274 \mathrm{~m}$. This specimen agrees with $G$. laysanus in all key characters: the orbit diameter $(2.75$ in HL) is less than the postorbital length; the teeth are of moderate size; the caudal fin is rounded (i.e., double emarginate) with produced outer rays; the caudal peduncle is longer than its depth; and the third anal spine is longer than the first dorsal spine (Katayama et al. 1982). The known range of the species is now the Emperor Seamounts, the Hawaiian Islands, Johnston Atoll, the Line Islands, New Caledonia, and the Sala-y-Gómez Ridge (Gilbert 1905, Fourmanoir 1971, Chen 1980, Katayama et al. 1982, Randall et al. 1985, Parin et al. 1997).

During this study we attempted to obtain additional literature, specimens, and visual sightings to clarify the identification of the Grammatonotus that we observed from the Pisces submersibles. To our dismay, most of these additional sources of information invoke additional taxonomic questions rather than clarifications. We conclude that the genus Grammatonotus is greatly in need of taxonomic revision. The potential for allometry in eye size and other characters, for sexual dimorphism, and for geographic variability in color pattern will likely necessitate the examination of numerous specimens over a large size range each from a number of localities to resolve the species composition of the genus. Unfortunately, the small size of fishes in the 
genus, the rugged habitats in which they often live, and the absence of sampling for deepwater fishes at Pacific island groups other than the Hawaiian Islands will make collection of the specimens necessary for this revision very difficult.

\section{Material Examined}

SPECIMENS. вРвм 22757. Grammatonotus laysanus (1 of 9 specimens, the others on loan). $123 \mathrm{~mm}$ SL. Hancock Seamount, Hawaiian Archipelago. NOAA ship Townsend Cromwell cruise TC7702, Sta. 52. 26 May 1977. 144-177 m. Nor'eastern bottom trawl.

в Рвм 37191. Grammatonotus laysanus juvenile. 39 mm SL. Kahe Point, O'ahu, Hawaiian Islands. 19 May 1989. 25 ft [7.6 m]. Hand net on sand. Collector, J. Culp.

врвм 37135. Grammatonotus sp. juvenile. $32 \mathrm{~mm}$ SL. Hao Atoll, Tuamotu Archipelago. $18^{\circ} 4^{\prime} 12^{\prime \prime} \mathrm{S}, 141^{\circ} 20^{\prime} 12^{\prime \prime}$ W. 2 June 1990. 705 m. Dredge. Collector, J. Poupin.

NMFSH P-113. Grammatonotus laysanus. $145 \mathrm{~mm}$ SL. SE Hancock Seamount, Hawaiian Archipelago. NOAA ship Townsend Cromwell cruise TC8205, Sta. 18. 6 November 1982. 140 fathoms [256 m]. Nor'eastern trawl.

вРвм 39292. Grammatonotus laysanus. $62 \mathrm{~mm}$ SL. Christmas Island, Line Islands. NOAA ship Townsend Cromwell cruise TC60, Sta. 53. 22 August 1972. 150 fathoms [274 $\mathrm{m}]$. Shrimp trawl.

NMFs HLIP-34. Grammatonotus sp. larva. $4.2 \mathrm{~mm}$ SL. $20 \mathrm{~km}$ west of Hancock Seamount, Hawaiian Archipelago. NOAA ship Townsend Cromwell cruise TC8405, Sta. 130. 27 July 1984. 0-25 m. Tucker trawl net 3.

NMFs HLIP-1. Grammatonotus sp. pelagic juvenile. $18.7 \mathrm{~mm}$ SL. South of O'ahu, Hawaiian Islands. NOAA ship Townsend Cromwell cruise TC32, Sta. 31. 80-121 m. Cobb midwater trawl.

Photographs of Grammatonotus crosnieri provided by W. Anderson (Grice Marine Biological Laboratory, December 2002):

MNHN 1978-79, $117 \mathrm{~mm}$ SL, Philippines, holotype of Callanthias crosnieri Fourmanoir (1981).

mUsorstom 3, Sta. 12, Philippines, length unknown, specimen illustrated in Anderson (1999).

Uncataloged?, $90 \mathrm{~mm}$ SL, locality unknown, received from P. Fourmanoir.

Uncataloged?, $71 \mathrm{~mm}$ SL, Philippines, received from P. Fourmanoir.

\section{ACKNOWLEDGMENTS}

We thank the Hawai'i Undersea Research Laboratory (HURL) for the opportunity and physical support that enabled us to do this research. Terry Kerby and Charles Holloway (HURL) provided expert submersible piloting, found the G. macropbthalmus for us, and enabled us to obtain the video images. Christopher Kelley (HURL), Jane Culp (HURL), Walter Ikehara (State of Hawai'i Department of Land and Natural Resources), Robert Moffitt (NOAA Fisheries Honolulu Laboratory), and Sean Corson (NOAA National Ocean Service) provided scientific assistance and discussions about the identification of the G. macropbthalmus. Jane Culp provided copies of the video and other data from these dives. Rachel Shackelford and Leping Hu (HURL) provided data on HURL bottomfish survey dives. The crew and other scientists aboard the R/V Ka'imikai-o-Kanaloa enabled us to complete our research. Ani Au, NOAA Fisheries Honolulu Laboratory librarian, obtained copies of references. Keiichi Nemoto (University of Hawai'i Joint Institute for Marine and Atmospheric Research) translated references from Japanese to English for us and provided assistance in contacting $\mathrm{E}$. Fujii in Japan. R. Moffitt, Michael Seki (NOAA Fisheries Honolulu Laboratory), and Arnold Suzumoto (Bernice P. Bishop Museum, Honolulu) made specimens available for examination. William D. Anderson Jr. (Grice Marine Biological Laboratory) provided unpublished information on nominal species of Grammatonotus. W. Anderson, R. Moffitt, and $\mathrm{C}$. Kelley reviewed the manuscript.

\section{Literature Cited}

Anderson, W. D., Jr. 1999. Callanthiidae. Groppos (also goldies and splendid 
perches). Pages 2553-2556 in K. E. Carpenter and V. H. Niem, eds. FAO species identification guide for fishery purposes. The living marine resources of the western central Pacific. Vol. 4. Bony fishes part 2 (Mugilidae to Carangidae). FAO, Rome.

Anderson, W. D., Jr., and G. D. Johnson. 1984. A new species of Callanthias (Pisces: Perciformes: Percoidei: Callanthiidae) from the southeastern Pacific Occean. Proc. Biol. Soc. Wash. 97 (4): 942-950.

Carpenter, K. E. 1999. Guide to orders and families. Pages 1548-1617 in K. E. Carpenter and V. H. Niem, eds. FAO species identification guide for fishery purposes. The living marine resources of the western central Pacific. Vol. 3. Batoid fishes, chimaeras and bony fishes part 1 (Elopidae to Linophrynidae). FAO, Rome.

Chave, E. H., and A. Malahoff. 1998. In deeper waters: Photographic studies of Hawaiian deep-sea habitats and life-forms. University of Hawai'i Press, Honolulu.

Chave, E. H., and B. C. Mundy. 1994. Deepsea benthic fish of the Hawaiian Archipelago, Cross Seamount, and Johnston Atoll. Pac. Sci. 48:367-409.

Chen, C.-H. 1980. Primary studies of demersal fish resources investigation on trawl grounds at Kanmu Seamount. Bull. Taiwan Fish. Res. Inst. No. 32:317-337. [In Chinese. English translation by W. G. Van Campen, 1983, NMFS SWFSC Honolulu Laboratory Translation No. 79.]

Eschmeyer, W. N., ed. 1998. Catalog of fishes. Calif. Acad. Sci. Cent. Biodiversity Res. Inf. Spec. Publ. No. 1. 3 vols. (recent revisions at http://www.calacademy.org/ research/ichthyology/catalog/ fishcatsearch.html).

Fourmanoir, P. 1971. Notes Ichtyologiques (IV). Cah. O.R.S.T.O.M., Ser. Oceanogr. 9 (4): 491-500.

. 1976. Formes post-larvaires et juvéniles de poissons côtiers pris au chalut pélagique dans le sud-ouest Pacifique. Cah. Pac. 19:47-88.

1981. Poissons (première liste). Resultats de Campagnes MUSORSTOM, I-Philippines (18-28 Mars 1976): 85102.
Fujii, E. 1986. Zoogeographical features of fishes in the vicinity of seamounts. Pages 67-69 in R. N. Uchida, S. Hayashi, and G. W. Boehlert, eds. Environments and resources of seamounts in the North $\mathrm{Pa}$ cific. NOAA Tech. Rep. NMFS 43.

Gilbert, C. H. 1905. The aquatic resources of the Hawaiian Islands. Section II. The deep-sea fishes. Bull. U. S. Fish Comm. 23 (2): 577-713.

Grigg, R. W. 1974. Distribution and abundance of precious corals in Hawaii. Pages 235-240 in Proc. 2nd Int. Coral Reef Symp. Great Barrier Reef Committee, Brisbane, Australia.

- 1981. Acropora in Hawaii. Part 2. Zoogeography. Pac. Sci. 35:15-24.

. 1984. Resource management of precious corals: A review and application to shallow water reef building corals. Pubbl. Stn. Zool. Napoli I Mar. Ecol. 5 (1): $57-$ 74.

Grigg, R. W., and F. M. Bayer. 1976. Present knowledge of the systematics and zoogeography of the order Gorgonacea in Hawaii. Pac. Sci. 30:167-175.

Günther, A. 1880. Report on the shore fishes procured during the voyage of the H.M.S. Challenger in the years 1873-1876. In Report on the scientific results of the voyage of the H.M.S. Challenger during the years 1873-1876. Zoology, 1 (pt. 6): 1-82, pls. 1-32. [Reprint by J. Cramer, 1963.]

Japan Fisheries Agency. 1974. Survey of the North Pacific seamounts. Report of Kaiyo Maru survey cruises, 1972 season. [In Japanese. English translation by T. Otsu. NMFS SWFSC Honolulu Laboratory Translation No. 54.]

Jones, G. P., M. J. Caley, and P. L. Munday. 2002. Rarity in coral reef fish communities. Pages 81-101 in P. F. Sale, ed. Coral reef fishes: Dynamics and diversity in a complex ecosystem. Academic Press, San Diego.

Kanou, K., G. Shinohara, and K. Shibukawa. 2003. Juveniles of a rare callanthiid fish genus Grammatonotus (Pisces: Perciformes) from Japan. Bull. Natl. Sci. Mus., Tokyo, Ser. A (Zool.) 29 (1): 39-46.

Katayama, M., T. Yamakawa, and K. Suzuki. 
1980. Grammatonotus surugaensis, a new serranid fish from Suruga Bay and the Straits of Osumi, Japan. Biogeogr. Soc. Jpn. 35 (4): 45-48.

Katayama, M., E. Yamamoto, and T. Yamakawa. 1982. A review of the serranid fish genus Grammatonotus, with description of a new species. Jpn. J. Ichthyol. 28 (4): $368-$ 374.

Kotthaus, A. 1976. Fische des Indischen Ozeans. Ergebnisse der ichthyologischen Untersuchungen während der Expedition des Forschungsschiffes "Meteor" in den Indischen Ozean, Oktober 1964 bis Mai 1963. A. Systematischer Teil, XVII. Percomorphi (7). "Meteor" Forsch.Ergebnisse, Reihe D, No. 23:45-61.

Masuda, H., K. Amaoka, C. Araga, T. Uyeno, and T. Yoshino, eds. 1984. The fishes of the Japanese Archipelago. Tokai University Press, Tokyo. Vol. 1 (text), Vol. 2 (plates).

1992. The fishes of the Japanese Archipelago. 3rd ed. Tokai University Press, Tokyo. Vol. 1 (text), Vol. 2 (plates).

Matsuura, K., and H. Tachikawa. 1994. Fishes washed up on beaches of Chichijima, Ogasawara Islands. Bull. Natl. Sci. Mus., Tokyo, Ser. A (Zool.) 20 (3): 131147.

Miskiewicz, A. G., C. C. Baldwin, J. M. Leis, and D. S. Rennis. 2000. Callanthiidae (yellow-fin basses, splendid perches). Pages 280-284 in J. M. Leis and B. M. CarsonEwert, eds. The larvae of Indo-Pacific coastal fishes: An identification guide to marine fish larvae. Fauna Malesiana Handbook 2. Brill, Leiden.

Mooi, R. D. 1993. Phylogeny of the Plesiopidae (Pisces: Perciformes) with evidence for the inclusion of the Acanthoclinidae. Bull. Mar. Sci. 52 (1): 282-326.
Mundy, B. C. In press. A checklist of the fishes of the Hawaiian Archipelago. Bernice P. Bishop Mus. Bull. Zool.

Okamura, O., and K. Amaoka, eds. 1997. Sea fishes of Japan. Yama-Kei Publishers Co., Tokyo.

Okamura, O., K. Amaoka, and F. Mitani, eds. 1982. Fishes of the Kyushu-Palau Ridge and Tosa Bay, Japan. Fisheries Resource Conservation Association, Tokyo.

Parin, N. V., A. N. Mironov, and K. N. Nesis. 1997. Biology of the Nazca and Sala y Gómez submarine ridges, an outpost of the Indo-West Pacific fauna in the eastern Pacific Ocean: Composition and distribution of the fauna, its communities and history. Adv. Mar. Biol. 32:145-242.

Parrish, F. A., K. Abernathy, G. J. Marshall, and B. M. Buhleier. 2002. Hawaiian monk seals (Monacbus schauinslandi) foraging in deepwater coral beds. Mar. Mam. Sci. 18 (1): 244-258.

Qui, B. 1999. Seasonal eddy field modulation of the North Pacific Subtropical Countercurrent: TOPEX/Poseidon observations and theory. J. Phys. Oceanogr. 29:24712486.

Randall, J. E. 1996. Shore fishes of Hawai'i. Natural World Press, Vida, Oregon.

Randall, J. E., P. S. Lobel, and E. H. Chave. 1985. Annotated checklist of the fishes of Johnston Island. Pac. Sci. 39:24-80.

Springer, V. G. 1982. Pacific Plate biogeography, with special reference to shorefishes. Smithson. Contrib. Zool. 367.

Trnski, T., and A. G. Miskiewicz. 1998. Callanthiidae: Yellow-fin basses. Pages 189-191 in F. J. Neira, A. G. Miskiewicz, and T. Trnski, eds. Larvae of temperate Australian fishes: Laboratory guide for larval fish identification. University of Western Australia Press, Nedlands, Western Australia. 